in psychiatric hospitals consisted of whipping the patients, one would hope that those who wished to retain it might be influenced by the discovery that the procedure was not effective in its purpose.

I am much more puzzled by Dr. Carr's list of 'practical realities'. Where does Dr Carr stand-in favour of compulsory attendance or not; curriculum teaching or not? The suppression of homosexual and heterosexual drives or not? And does he subscribe or not to the political system in which the educational services are organised?

It rather seems that he is on the side of 'freedom' at a level which is beyond that which many people would consider desirable. If, however, there is to be no compulsion on these matters there would be little left where coercion would have to apply.

Compulsion is, in fact, inextricably bound up with the law concerning education; but at times the nature of the application of that compulsion is too high a price to pay for some questionable benefits. The Report presents the view that corporal punishment is such an instance.

$$
\begin{aligned}
& 29 \text { Antrim Mansions, } \\
& \text { Antrim Road, } \\
& \text { London } N_{3} W_{4} \mathrm{XU}
\end{aligned}
$$

J. H. KAHN

\section{THE PSYCHIATRIST'S RESPONSIBILITIES IN MENTAL HANDICAP}

Dear Sir,

Dr Day draws attention to some special aspects of the practice of psychiatry with the mentally handicapped and concludes that these give rise to a 'serious misconception' about clinical responsibilities in this field compared to general psychiatry (Bulletin, December 1977). His argument is based on the number of mentally handicapped persons whose primary needs are for social or educational measures, a proportion of whom are in hospitals.

Whilst broadly agreeing with this, I would point out that the services for the mentally ill are also involved with an increasing diversity of patients presenting as social and other 'non-medical' problems. One essential difference is the way in which our general psychiatric colleagues have applied themselves over the years with greater energy and in much larger numbers to expanding the boundaries within which legitimate psychiatric contributions can be made.

Dr Way (Bulletin, March 1978) indicates some of the largely unexplored and exciting territory in mental handicap which it seems to me we could investigate more effectively if we did not have to devote so much time to the multidisciplinary doctrine, rather than its practice. Dr Clark (.Joumal, 131, 553) reminds us of the rise and relative fall of the 'therapeutic community'; in a decade hence we could be reading a similar account of the fate of the multidisciplinarians.

Mental Handicap Service,

T. L. Pilknngton

Brierthorpe,

${ }_{16} 6_{3}$ Durham Road,

Stockton-on-Tees,

Cleveland TSIg oEA

\section{DR SEMYON GLUZMAN}

Dear Sir,

On I I May Dr Leila Harvey arranged a meeting in Manchester to promote International Gluzman Day, 12 May, when Dr Semyon Gluzman had been in captivity for six years; he will have one more year to serve in a Soviet forced labour camp plus three years Siberian exile. The meeting, attended by professors, consultants, G.P.s, interested members of the public, and addressed by three psychiatrists, expressed strong concern that pressure and publicity should be maintained on Dr Gluzman's behalf, one of the bravest members of our profession. Almost alone among doctors inside the Soviet Union he exposed his country's abuse of psychiatry for the purpose of political repression. A telegram bearing 34 signatures was dispatched from the meeting to President Brezhnev appealing for Dr Gluzman's release.

In order to ensure that the Soviet authorities are kept aware of continued concern by doctors in the West it is planned that a constant flow of letters to Dr Gluzman be maintained using a method which makes it certain that at least some reach their destination. Details of the method, and also further information on Dr Gluziman may be obtained from Dr S. Bloch, Warneford Hospital, Oxford OX3 73X or Dr Leila Harvey, 5 Firs Avenue, Firwood, Manchester Mi6 oEP. Tel: o6I-88 I 685I.

Macartney Day Department, S. Shapar

North Manchester General Hospital

(Division of Psychiatry),

Crumpsall,

Manchester M8 6RB

\section{LEAFLET FOR PARENTS OF STILLBORN GHILDREN}

DeAr Sir,

I was very interested to read about this leaflet (Bulletin, April, p 69) and would agree with most of 
its proposed contents. They seem very appropriate, sensible and enlightened. However, I have considerable reservations as to whether a leaflet would be the best way of dealing with this.

At a time of considerable grief and stress for the whole family providing them with a leaflet could appear to reinforce the currently prevalent attitude of denial of these feelings, at least in some quarters. I wonder how many parents, particularly mothers, would even be able to read through this leaflet, considering the extent and nature of their distress at this time.

Personally, I do not think that there is any alternative but for one of the professionals involved, whether doctor, nurse or social worker, to deal personally with the mother's and the family's distress.

Perhaps the contents of this leaflet could be expanded to provide more information for the professionals coming into direct contact with these mothers and parents, particularly nurses and health visitors. Giving a leaflet to a mother or parents at a time like this could further inhibit the facilitation of the mourning process.

B. LENA

Department of Child and Family Psychiatry,

District General Hospital,

Kings Drive,

Eastbourne,

East Sussex BN21 2UD

\section{IN NEED OF SYMPATHETIC MODERNIZATION}

Dear Sir,

Following Ezra's column in your March issue (p 43), I couldn't resist sending you excerpts from this Australian advertisement for a desirable post from the March 1978 Australian and New Zealand Fournal of Psychiatry. The italics are mine.

'Mental Health Authority, Victoria Consultant Phychiatrist (sic)

Applications are invited ... the Unit is a 36 bed unit, conducted jointly by the MHA of Victoria and the Department of Psychiatry ... It is centrally located only a short distance from the centre of Melbourne and is situated in attractive parklands close to schools, universities and amenities. Housing may be available ... There are five Consultant Psychiatrist positions within the Unit, each leading multidisciplinary teams. Four of these teams practise electric (sic) psychiatry, while the fifth is concerned specifically with psychotherapy, both individual and group ....'

Regretfully I couldn't stop laughing sufficiently to attempt Ezra's competition to be a HASbeen.

Michael Duke

(alias Araxerxes Brevimanus)

Royal Prince Alfred Hospital, Camperdown, NSW 2050, Australia

\section{FORTHCOMING EVENTS}

\section{Royal Free Hospital School of Medicine}

The next course on Integrated Basic Sciences, intended for those preparing for the M.R.C.Psych. Preliminary Test and Part I DPM Examination will start on ro October at the Royal Free Hospital, on Tuesdays from 2-5 p.m. The course covers three academic terms and the subjects covered include physiology, pharmacology, neuro-physiology and genetics. The cost of $f 80$ may be reclaimed from the appropriate Area Health Authority. Application forms and further details from Dr Fay Fransella, Academic Department of Psychiatry, Royal Free Hospital, Pond Street, London NW3 2QG.

\section{Training in Psychodrama}

Dr Dean Elefthery, current President of the American Society of Group Psychotherapy and Psychodrama, will be taking a training group of the International Foundation for Human Relations at the Uffculme Clinic, beginning in October 1978. Course will consist of a total of 21 days, divided into three-day sessions over a $2 \frac{1}{2}$-year period. The first session will take place on 27,28 and 29 October, and the fee will be $£ 75$, excluding hotel expenses. Applicants should have some previous training in psychotherapy. Further details from Dr Martin H. Davies, Uffculme Clinic, Queensbridge Road, Moseley, Birmingham $\mathrm{Br}_{3}$ 8QD. 